\title{
Correlates of alternative migratory strategies in western bluebirds
}

\author{
C.A. Dale ${ }^{1}$, J. J. Nocera ${ }^{2}$, S.E. Franks ${ }^{3}$, T. K. Kyser ${ }^{4, \dagger}$ and L.M. Ratcliffe ${ }^{1}$
}

${ }^{1}$ Department of Biology, Queen's University, Kingston, Ontario, K7L 3N6, Canada

${ }^{2}$ Faculty of Forestry and Environmental Management, University of New Brunswick, Fredericton, New Brunswick, E3B 5A3

${ }^{3}$ British Trust for Ornithology, Thetford, UK

${ }^{4}$ Department of Geological Sciences and Geological Engineering, Queen's University, Kingston, Ontario, K7L 3N6

Corresponding author: C.A. Dale, Department of Biology, Queen's University, Kingston, Ontario, K7L 3N6, Canada. E-mail: 9cad@ queensu.ca

$†$ Deceased

Decision date: 04-Mar-2019

This article has been accepted for publication and undergone full peer review but has not been through the copyediting, typesetting, pagination and proofreading process, which may lead to differences between this version and the Version of Record. Please cite this article as doi: [10.1111/jav.02031].

'This article is protected by copyright. All rights reserved.' 


\begin{abstract}
Partial migration occurs when only some animals in a population migrate. While evidence suggests that migratory strategies are partially controlled by genes, individual and environmental conditions which alter the cost-benefit trade-off of migration among individuals are also likely to play a role. Three hypotheses have been advanced to explain condition-dependent partial migration: the arrival time, dominance, and body size hypotheses. In this study, we asked whether these hypotheses explained differences in migratory strategy among individuals in a partially migratory population of western bluebirds (Sialia mexicana) breeding in southern British Columbia, Canada. We used stable hydrogen isotope signatures in claw tissue to determine migratory strategy of individual bluebirds, and examined patterns of migration at both individual and population levels. The proportion of resident bluebirds varied significantly over the three years of the study, and across study sites. Several migrants switched to the resident strategy between years; however, we found no evidence of strategy switching in the opposite direction. Young birds were significantly more likely to be resident than older birds, a pattern which could arise if early arrival is particularly important for birds obtaining a territory for the first time. Furthermore, young females were the most likely of all sex-age classes to be resident, which may reflect a survival advantage of residency for young females. Finally, birds mated assortatively by migratory strategy and isotopic evidence suggests that members of a pair often wintered in the same place. Our results provided no support for the dominance or body size hypotheses, and only limited support for the arrival time hypothesis in bluebirds. However, taken together, we suggest that our findings indicate that social factors may influence migratory strategies in this system.
\end{abstract}

Keywords: partial migration, migratory strategies, arrival time hypothesis, dominance hypothesis, body size hypothesis, sociality, western bluebirds, hydrogen isotopes

'This article is protected by copyright. All rights reserved.' 


\section{Introduction}

Migration is an integral part of the annual cycle of many species, from invertebrates to mammals.

However, although migration is typically thought of as a life history strategy shared by entire populations or species, migratory behaviour often varies among individuals - from direction (e.g., Berthold et al. 1992) and route (e.g., Sandberg and Moore 1996), to timing (e.g., Studds et al. 2008) and distance (e.g., Dale and Leonard 2011). An understanding of why migratory behaviour varies among individuals can reveal both proximate and ultimate causes of migration, and shed light on the evolution of long distance movement in animal populations (Lundberg 1988, Chapman et al. 2011a, Pulido 2011). Furthermore, because migration is inextricably linked to other parts of the annual cycle, variation in migratory behaviour may arise from individual differences in non-breeding (e.g., Studds et al. 2008) or breeding (e.g., Catry et al. 2013) experience, and may carry over to affect survival and reproductive success in other parts of the annual cycle (e.g., Dale and Leonard 2011). Thus, understanding the causes and consequences of variation in migratory behaviour is necessary to better predict population trends (Gilroy et al. 2016), and is particularly important in the current context of rapid, human-induced changes to climate and land-use (Chapman et al. 2011b), which have been linked to population declines in migratory species worldwide (Wilcove and Wikelski 2008, MettkeHofmann 2017).

Perhaps the most extreme example of variation in migratory behaviour occurs when individuals within one population adopt entirely different migratory strategies: some migrate, while others remain resident year-round. This "within population migratory dimorphism” (Chapman et al. 2011b; pg. 1764) is known as partial migration. It is perhaps the most common form of migration, found across a wide variety of taxa (Chapman et al. 2011b), and is particularly common in birds (Pulido et al. 1996, Berthold 2001). For example, $>50 \%$ of the migrant passerine species breeding at high latitudes (north of $39^{\circ} \mathrm{N}$ ) in North America are thought to be partial migrants (Jahn et al. 2012).

Despite the prevalence of partial migration in birds, the mechanisms determining individual migratory strategies are still not well understood. Captive breeding studies have demonstrated that incidence, amount, and direction of migratory activity are heritable in partial migrants (Berthold and Querner 1981, 1982, Biebach 1983, Berthold et al. 1990, Helbig 1991), suggesting that migratory strategy is genetically determined (Berthold 1988, Pulido et al. 1996). However, field studies of partial migrants have provided a

'This article is protected by copyright. All rights reserved.' 
wealth of evidence that migratory strategies are also shaped by individual or environmental condition. For example, in many species, variation in migratory behaviour appears to be driven by individual asymmetries in variables such as sex (e.g., Smith and Nilsson 1987, Belthoff and Gauthreaux 1991, Fudickar et al. 2013, Pérez et al. 2014), age (e.g., Lundberg 1985, Able and Belthoff 1998, Holte et al. 2016), and body size (e.g., Hegemann et al. 2015), or by environmental factors such as habitat (Adriaensen and Dhondt 1990). Moreover, longitudinal studies of several species show that some individuals can switch strategies between years (e.g., Chan and Kikkawa 1997, Able and Belthoff 1998, Gillis et al. 2008, Ogonowski and Conway 2009, Palacín et al. 2011, Pérez et al. 2014, Hegemann et al. 2015). These findings suggest that ecological factors, rather than genetics, may be the main determinant of individual migratory strategies.

Given the importance of individual and environmental condition in shaping migratory behaviour, much research has focused on identifying the ecological factors that result in some individuals migrating while others remain resident. Three hypotheses have commonly been advanced to explain the patterns in migratory strategy often seen in partially migratory populations. The arrival time hypothesis posits a selective advantage to residency for the sex that establishes territories, and thus predicts a correlation between migratory strategy and sex (Ketterson and Nolan 1976). The dominance hypothesis proposes that limited resource availability during the non-breeding season results in dominant individuals compelling subordinates to migrate (Ketterson and Nolan 1976, Gauthreaux 1982). Finally, the body size hypothesis suggests larger individuals may better tolerate the environmental challenges of residency, and predicts that smaller individuals will be more likely to migrate (Ketterson and Nolan 1976; 'thermal tolerance hypothesis' in Chapman et al. 2011b).

While studies of partial migration have provided support for all three hypotheses, there are also many systems where observed patterns of migratory behaviour do not match the predictions generated by the arrival time, dominance or body size hypotheses, suggesting other factors are at work. For example, in Tasmanian silvereyes (Zosterops lateralis lateralis), an individual's migratory strategy is not related to sex, age, or size, contrary to the predictions of the arrival time, dominance, and body size hypotheses (Chan and Kikkawa 1997). Thus, it is becoming increasingly apparent that we need to consider ecological factors beyond those encompassed in the three classic hypotheses when attempting to understand partial migration. In silvereyes, social influences may determine individual migratory strategy. Chan (1994) found that some birds 
only developed migratory restlessness in the presence of others, an observation which led him to suggest interactions with other individuals may be a key cue for initiating migration in this species (Chan and Kikkawa 1997, Chan 2005). Social influences have been proposed to play a role in determining migratory strategies in other species, such as great bustards (Otis tarda; Palacín et al. 2011), and pied avocets (Recurvirostra avosetta; Chambon et al. 2018), where strategies appear to be influenced by an individual's integration into winter flocks.

In this study, we investigated the correlates of alternate migratory strategies in a population of western bluebirds (Sialia mexicana) breeding in the Okanagan Valley of British Columbia (BC), Canada. Western bluebirds occur throughout western North America from Mexico to BC, and migratory strategies vary throughout the range: southern bluebird populations are largely resident, while northern populations are partially or entirely migratory (Guinan et al. 2008). Our study site in southern BC is close to the northern limit of the species' breeding range, and the population is partially migratory (Campbell et al. 1997). During the spring and summer, western bluebirds breed throughout the Okanagan; during the winter, some individuals migrate, while others remain (Cannings 2009). Data from Christmas Bird Counts indicate that overwintering bluebirds were relatively rare in the Okanagan prior to the mid-1980s, but numbers have been increasing since then (National Audubon Society 2010, Willis 2013, see Supplementary material Appendix 1, Figure A1), suggesting that residency is a recently established and increasingly used strategy in this population.

We first determined whether individual western bluebirds were migrants or residents using hydrogen isotope ratios in claw tissue, and then examined population and individual patterns of migration to investigate the ecological factors shaping migration behaviour in this species. We asked whether migratory strategies varied over years or between sites, and whether individuals were consistently migratory or resident. We also examined sex, age, and size patterns in relation to migratory strategy and asked whether these patterns were consistent with the arrival time, dominance, or body size hypotheses. Finally, to investigate possible social influences shaping migratory behaviour, we asked whether birds paired assortatively by migratory strategy.

The natural history of western bluebirds has been well-studied, allowing us to make predictions about the patterns expected under the arrival time, dominance, and body size hypotheses. Although both members of a pair defend the breeding territory against intruders (Guinan et al. 2008), male characteristics, such as aggression, have been linked to settlement on high quality territories (Duckworth 2006). Furthermore, 
when bluebird pairs divorce, males typically remain on the territory while females leave (CAD pers. obs.). Taken together, these observations suggest that males are responsible for territory establishment; thus, under the arrival time hypothesis, we predicted that females would be more likely to migrate than males.

Additionally, in male bluebirds, dominance is related to age: older birds displace younger birds on breeding territories in the spring (Brawn 1984). Thus, under the dominance hypothesis, we predicted that young males would be more likely to migrate than older males. Finally, under the body size hypothesis, we predicted that smaller individuals would be more likely to migrate.

\section{Methods}

\section{Study sites and field methods}

We conducted this study across a $70 \mathrm{~km}$ range in the southern Okanagan Valley of British Columbia, Canada (from $49^{\circ} 33^{\prime} \mathrm{N}, 119^{\circ} 39^{\prime} \mathrm{W}$ to $49^{\circ} 5^{\prime} \mathrm{N}, 119^{\circ} 36^{\prime} \mathrm{W}$; Figure 1). Western bluebirds are secondary cavity nesters, and readily breed in artificially constructed nest boxes. To access established breeding populations, we sought permission to use existing box trails from local bluebird enthusiasts. Because these trails were set up by different people over many years, boxes were unevenly distributed across a wide variety of habitats, from relatively undeveloped range lands to active vineyards and hiking trails. Sites also ranged widely in size (from approximately 0.5 to 66.5 ha) and number of nest boxes (from 12 to 116 ).

We captured birds during the winter (Feb - Mar) of 2011 and 2012, and the breeding season (Apr Aug) of 2011, 2012, and 2013. During the winter, we used a passive mist-netting approach to catch birds at three sites frequented by small flocks of wintering bluebirds. Once birds began to defend nest boxes at the beginning of the breeding season (late March and early April), we switched to an active mist-netting approach at ten sites containing bluebird nest box trails, using a decoy and playback of male song to simulate a conspecific territorial intrusion. As the breeding season progressed, we also used box traps to catch females incubating eggs, and both males and females feeding nestlings.

We banded captured birds with a numbered metal leg band and a unique combination of three coloured leg bands to allow individual identification from a distance. We sexed individuals by plumage, and assessed molt limits to age them as second year (SY; individuals hatched the previous summer and in their first breeding season) or after second year (ASY) as described by Shizuka and Dickinson (2005). We weighed each individual with a spring balance, measured tarsus length with callipers, and measured wing chord and

'This article is protected by copyright. All rights reserved.' 
tail length with a ruler. For isotopic analyses, we plucked the eighth secondary feather from one wing, and clipped a 1-2mm segment from the tip of the rear claw (C1) on both feet. In total, we sampled 203 adult western bluebirds: 123 males (112 captured once, 11 captured twice) and 80 females (61 captured once, 16 captured twice, and 3 captured in all three years of the study).

\section{Hydrogen isotope analysis}

To distinguish between migrant and resident western bluebirds, we analyzed stable hydrogen isotopes in claw tissue. The ratio of heavy to light hydrogen in precipitation $\left(\delta \mathrm{D}_{\mathrm{p}}\right)$ varies with latitude in North America (Sheppard et al. 1969, Bowen et al. 2005). The isotopic signature at a given location is incorporated into the food web and into animal tissues grown at that location (Estep and Dabrowski 1980, Hobson and Wassenaar 1997). Thus, hydrogen isotope ratios in tissue can act as a record of an individual's geographic history (Chamberlain et al. 1997, Hobson and Wassenaar 1997) and can be used to distinguish between individuals using different movement strategies (e.g., dispersers vs. site-faithful individuals: Hobson et al. 2004, Studds et al. 2008; individuals wintering in different areas: Bearhop et al. 2005; migrants vs. residents: Hegemann et al. 2015).

In partially migratory systems, hydrogen isotope analysis enables us to distinguish between individuals wintering in different locations (i.e., migrants vs. residents), as long as the tissue analyzed was grown on the wintering grounds. Western bluebirds molt once a year, on the breeding grounds in the late summer and early fall (Pyle 1997), so feather isotope signatures reflect breeding ground values. However, unlike feathers, claws grow continuously throughout the year, and claw keratin isotopic ratios reflect an individual's location over the previous several weeks to months (Bearhop et al. 2003, Fraser et al. 2008, Hahn et al. 2014). Therefore, claw hydrogen isotope $\left(\delta D_{c}\right)$ signatures of bluebirds captured in the early spring should reflect their location during the previous winter.

We conducted isotope analyses at the Queen's Facility for Isotope Research (QFIR) in Kingston, Ontario. We soaked claw samples in a 2:1 chloroform:methanol solution for 24 hours, then rinsed them with the same solution and allowed them to equilibrate with lab air for approximately 72 hours. After cleaning, we weighed samples into silver capsules (at approximately $0.10 \mathrm{mg}$ ), which we then outgassed in a $100^{\circ} \mathrm{C}$ oven for 24 hours to remove surface water. Samples underwent pyrolysis at $1450^{\circ} \mathrm{C}$ in a reduction furnace (Finnigan TC/EA) to produce hydrogen gas. This gas was delivered to an isotope ratio mass spectrometer

'This article is protected by copyright. All rights reserved.' 
(Finnigan MAT Delta ${ }^{\text {Plus }}$ XP) via a Conflo III interface. Results of hydrogen stable isotope analysis are expressed in parts per thousand (\%) relative to Vienna Standard Mean Ocean Water (VSMOW).

For every 18 claw samples, 7 laboratory standards with known $\delta \mathrm{D}$ ratios were weighed into silver capsules and analyzed alongside sample material. We used both mineral (brucite from the University of Michigan and Georgia kaolinite clay), and organic (double-crested cormorant (Phalacrocorax auritus) feather keratin) standards. Standard deviations for repeated measurements of standards were 4-5\% (kaolinite: $-60 \pm$ $4 \%$, $n=74$; brucite: $-95 \pm 5 \%, n=58$; cormorant: $-59 \pm 5 \%$, $n=29$ ). Within each run, we also ran duplicate samples for 1-3 individuals. Because claw samples were too small to divide for analysis, we used the samples from $\mathrm{C} 1$ on different feet as duplicates. Duplicated claw samples $(\mathrm{n}=32)$ differed by $5.0 \pm 3.6 \%$; visual inspection of duplicate values indicated that none of the birds would have been assigned to different migratory strategies based on the two claw samples. For duplicated claw samples, we included only the first isotopic signature obtained in further analyses.

\section{Assigning migratory strategies}

We first tested the prediction that claw isotope signatures would differ between migrant and resident bluebirds by comparing the $\delta \mathrm{D}_{\mathrm{c}}$ signatures of birds with known migratory strategies. Most western bluebird populations in British Columbia are migratory (Campbell et al. 1997), and overwintering birds are locally common only in the southern Okanagan (Cannings 2009, Cannings pers. com.); thus, we defined birds as known residents if they were captured or seen in the Okanagan Valley during the winter (1 January -15 March), and as known migrants if they were captured at Rock Creek, a site approximately $50 \mathrm{~km}$ east of the Okanagan Valley, during the breeding season. In total, we obtained claw samples from 12 known residents and 10 known migrants.

We tested whether claw hydrogen isotope signatures differed between known migrants and residents, and found that migrant $\delta \mathrm{D}_{\mathrm{c}}$ signatures were significantly heavier than resident $\delta \mathrm{D}_{\mathrm{c}}$ signatures $(\mathrm{t}=7.68$, $\mathrm{df}=19.62, \mathrm{p}<0.001$; Figure 2a). The ranges of migrant and resident $\delta \mathrm{D}_{\mathrm{c}}$ signatures overlapped slightly, and the isotopic signatures of known migrants and residents varied by $10-15 \%$ between years. However, the difference in signatures between strategies was considerably larger than the interannual variation: the mean claw signature of known migrants was approximately $34 \%$ heavier than that of known residents (Table 1).

'This article is protected by copyright. All rights reserved.' 
We then used a likelihood assignment testing approach (Royle and Rubenstein 2004), incorporating analytical error (Wunder and Norris 2008), to determine the migratory strategy of bluebirds captured during the breeding season. First, we used isotope signatures of individuals with known migratory strategies to establish the mean and standard deviation of the distribution of $\delta \mathrm{D}_{\mathrm{c}}$ values for migrant and resident birds. These individuals included the 22 western bluebirds with known migratory strategies ( $\mathrm{n}=10$ migrants; 12 residents) described above. To strengthen our assignment, we followed the approach of Wassenaar and Hobson (2001) and included the isotope signatures of six heterospecifics with known migratory strategies, all captured in the Okanagan in the winter and spring of 2011. The isotope signatures of these six heterospecifics - two European starlings (Sturnus vulgaris; resident) and four mountain bluebirds (Sialia currucoides; migrant) - fell within the range of known migrant/resident western bluebirds.

For each unknown origin individual sampled, we then calculated the probability that it belonged to the migrant or the resident group using a normal likelihood function (Royle and Rubenstein 2004). Because we did not have prior information about the relative abundance of migrants and residents, we used a uniform prior probability (i.e., prior probability $=1$ ). To incorporate analytical error, we used our repeated measurements of laboratory standards (brucite, kaolinite, and cormorant feather keratin) to establish a standard deviation for $\delta \mathrm{D}$ measurements. Then, for each stable isotope observation of each individual, we simulated 10000 values by drawing randomly from a distribution with a mean equal to the original stable isotope observation, and a standard deviation equal to the SD of the lab standards (Wunder and Norris 2008; Franks et al. 2012), generating 10000 datasets. For each individual in each dataset, we then determined the probability that it was a migrant or a resident as described above, and assigned it to the strategy with the greater probability of origin. Finally, we examined the distribution of assignments from the simulated datasets, and considered individuals to have employed the strategy with the greatest number of assignments out of 10000 simulations.

We tested our assignment using leave-one-out-cross-validation of individuals of known migratory strategy (Franks et al. 2012, Bugajski et al. 2013). This approach removes one sampled individual from the analysis and redefines the distribution of $\delta \mathrm{D}_{\mathrm{c}}$ values for migrants and residents using the remaining individuals, then attempts to classify the removed individual based on this new distribution. During crossvalidation, 26 of 28 individuals (93\%; 13 migrants and 13 residents) were assigned to the correct migratory

'This article is protected by copyright. All rights reserved.' 
strategy. Of the 26 correctly assigned individuals, 19 (73\%) were assigned correctly $100 \%$ of the time (i.e., in all simulations), and all 26 (100\%) were assigned correctly at least $80 \%$ of the time. Based on the results of our cross-validation, and approaches used in similar studies (Wunder and Norris 2008, Franks et al. 2012, Bugajski et al. 2013), we included bluebirds with unknown migratory strategy in subsequent analyses only if they were assigned to a migratory strategy with at least $80 \%$ confidence (i.e., in $\geq 8000$ of the 10000 simulations).

We also accounted for the fact that claws grow continuously, so while they maintain an ongoing record of the isotopic composition of an individual's diet, they only retain that information for a limited time. Thus, we needed to determine the date after which claws no longer provided reliable information about winter location. Previous studies indicate that passerine claws grow at a rate of approximately $0.04 \mathrm{~mm} \mathrm{~d}^{-1}$, and therefore retain information about winter location for one to two months after individuals return to the breeding grounds (Bearhop et al. 2003, Fraser et al. 2008, Hahn et al. 2014). Using the formula detailed in Hahn et al. (2014), we determined that the time period represented by the tip of the rear claw in bluebirds was approximately 71 days, meaning that within the first six to eight weeks after birds return in the spring, claw isotope ratios should represent their winter location. Most migrant western bluebirds return to the Okanagan Valley between mid-March and mid-April (Campbell et al. 1997), suggesting the cut-off date should be in mid-May. To verify this, we investigated the rate of isotopic change in western bluebird claws by sampling the claws of six known migrants at our Rock Creek site several times over the course of the 2012 breeding season. We found that the claws of these known migrants ceased to reflect the individuals' true migratory strategy between 9 May and 2 June 2012, again suggesting that a cut-off date in mid-May would be appropriate. Almost all of the bluebirds we captured in May were caught before 17 May; thus, we established a cut-off date of 17 May for assigning resident status based on claw isotope signatures.

Although we could not assign residency after our cut-off date, five of the thirty bluebirds captured after 17 May were assigned to the migratory strategy with $70-90 \%$ confidence, and we chose to include these individuals in analyses as migrants. Since claw growth during the breeding season leads to $\delta \mathrm{D}_{\mathrm{c}}$ signatures resembling those of residents for all individuals, regardless of migratory strategy, birds with 'migrant' claw isotope signatures after the cut-off date must have migrated.

'This article is protected by copyright. All rights reserved.' 
Using a likelihood assignment approach allowed us to assign the majority of sampled bluebirds to either the migrant or resident strategy. However, because the $\delta \mathrm{D}_{\mathrm{c}}$ distributions for known migrants and known residents overlapped, individuals with claw signatures in the area of overlap could not be assigned with $>80 \%$ confidence to either strategy. The unassignable range (or gap between the assigned resident with the most enriched $\delta D_{c}$ signature and the assigned migrant with the most depleted $\delta D_{c}$ signature) was $6 \%$ (Table 1 ). This gap is somewhat smaller than those used to define individuals with different movement strategies in other, similar studies (e.g., Hegemann et al. (2015) viewed migrant and resident skylark claw $\delta \mathrm{D}$ signatures to be separated by a minimum of $\sim 15 \%$; Studds et al. (2008) considered American redstarts (Setophaga ruticilla) to be dispersers only if feather $\delta \mathrm{D}$ signatures differed by more than $9 \%$ between years, otherwise individuals were considered site-faithful). The smaller unassignable gap in our study could pose a concern, given other studies where high levels of inter-individual variation in $\delta \mathrm{D}$ signatures were reported in tissues grown at the same location (e.g., Wunder et al. 2005, Rocque et al. 2006, Langin et al. 2007).

To address this possible issue, we analyzed hydrogen isotope signatures in feathers for a subset of individuals ( $\mathrm{n}=30 ; 20$ migrants and 10 residents), to determine whether the differences we observed in $\delta \mathrm{D}_{\mathrm{c}}$ values could be explained simply by variation among individuals, rather than differences in location. Western bluebird feathers are molted on the breeding grounds (Pyle 1997); as such, we predicted that feather $\delta \mathrm{D}$ signatures would be similar across individuals if location is the most important factor leading to variation in $\delta \mathrm{D}$, but variable if differences among individuals contribute significantly to variation. The subset of individuals for which we analyzed feather $\delta \mathrm{D}$ values consisted of birds breeding across the majority of the range of study, and included both individuals with known migratory strategies (7; all resident) and individuals with assigned migratory strategies (23; 20 migrants and 3 residents). Feathers were analyzed using the methods outlined above for claw samples. We found no difference between the feather $\delta \mathrm{D}$ signatures of migrant and resident birds $(t=0.28, \mathrm{df}=16.59, \mathrm{p}=0.79$; Figure $2 \mathrm{~b})$, suggesting that differences in claw $\delta \mathrm{D}$ signatures are reflective of true differences in location, and not simply variation among individuals.

\section{Data analysis}

All statistical analyses were conducted in R (version 3.1.3, R Core Team 2015).

Individual and population patterns of migration 
For a subsample of recaptured birds ( $\mathrm{n}=23$ ), we were able to assign individuals to a migratory strategy in two or more years. For these individuals, we used Fisher Exact tests to determine whether sex or previous migratory strategy influenced migration in subsequent years. Although we recaptured three of these individuals in two consecutive years, only data from the first recapture were included in analyses, to reduce pseudoreplication.

We used Spearman rank correlation tests to determine whether the proportion of residents was correlated across years within sites, and a Cochran-Mantel-Haenszel test to determine whether the proportion of residents varied across years after controlling for site effects.

\section{$\underline{\text { Individual correlates of migratory strategy }}$}

To investigate whether individual characteristics were correlated with migratory strategy in bluebirds, we used a generalized linear mixed model with a binomial error structure (function glmer, $\mathrm{R}$ package lme4). We used migratory strategy (migrant vs. resident) as the response variable, and sex, age, and a measure of body size (tarsus length) as fixed effects. We also included the interaction between sex and age as a fixed effect, because studies have demonstrated that the relationship between age and migratory strategy can vary for males and females (e.g., Jahn et al. 2010, Palacín et al. 2011). We included year and site as random effects to account for temporal and spatial patterns in migratory strategy, and individual nested within site as a random effect to account for the individuals caught and assigned to a migratory strategy in multiple years. We started with the full model and worked backward, eliminating fixed effects based on likelihood ratio testing to arrive at the minimum adequate model. We checked model assumptions on the residuals of the minimum adequate model.

We excluded birds with known migratory strategies (the winter captured birds and the Rock Creek migrants; $n=21$ ) from this analysis. We also excluded birds whose breeding site was unknown (birds captured at one of our study sites but not seen again during the breeding season; $n=6$ ), and individuals for which we did not have a tarsus measurement $(n=4)$.

\section{Breeding correlates of migratory strategy}

We monitored birds over the breeding season, and considered individuals to be paired if they were observed engaging in any nesting behaviour together (e.g., nest building, box defence, feeding nestlings). For 54 pairs, we obtained claw samples and isotope signatures for both members of the pair, and in 44 of those 
cases we could assign a migratory strategy to both the male and the female. Eight of the 54 pairs were seen breeding together in multiple years (7 pairs in two years, 1 pair in three years); however, we included each pair only once in analyses to reduce pseudoreplication.

We tested for assortative mating by migratory strategy in these 44 pairs using a chi-squared test. To determine whether members of a pair wintered in the same area, we also asked whether the $\delta \mathrm{D}$ signatures of members of a pair were correlated, using all 54 of the pairs from which we obtained male and female claw samples. Because neither female nor male $\delta \mathrm{D}$ values were normally distributed, we used a non-parametric Spearman rank correlation to test for an association between the $\delta \mathrm{D}$ signatures of the members of a pair.

\section{Results}

\section{Individual and population patterns of migration}

Over the course of the study, we captured 203 western bluebirds; using $\delta \mathrm{D}_{\mathrm{c}}$ signatures, we determined migratory strategy for 158 (78\%) of those individuals. We caught 30 of our banded birds more than once (27 in two years; 3 in three years), and were able to assign migratory strategy in all years of capture for 23 of the 30 recaptures ( 7 males and 16 females).

Of these 23 birds for which we had information about migratory strategy in multiple years, 9 were consistently resident and 9 were consistently migratory. However, 5 of the 23 birds (22\%) switched migratory strategies between the first and second years of capture. While it is difficult to draw inferences from this small sample, we found birds that had migrated the previous winter were significantly more likely to switch strategies than those that had remained resident (Fisher's exact test, $\mathrm{p}=0.003$ ); all five of the individuals that switched strategies changed from migration to residency. We only observed strategy switching in females; however, statistically, there was no difference between sexes in the proportion of birds that switched strategies (Fisher's exact test, $\mathrm{p}=0.27$ ), likely due to our small sample size of recaptured males in particular.

The proportion of captured individuals assigned to the resident strategy varied widely, from $18 \%$ in 2011 to 73\% in 2013 (Table 2). However, this variation is likely partly due to changes in sampling effort across sites and years, because proportion of residents also varied widely between study sites: birds at some sites were almost exclusively resident (e.g., Summerland, Figure 1), while those at other sites were entirely migrant (e.g., Thomas Ranch, Figure 1). Furthermore, the proportion of residents at a site was significantly correlated between years (2011-2012: $\mathrm{n}=9$ sites, $\rho=0.96, \mathrm{p}<0.001 ; 2012-2013$ : $\mathrm{n}=8$ sites, $\rho=0.92, \mathrm{p}=0.001)$, 
suggesting that within sites, migratory patterns were consistent over time. The relationship between site and migratory strategy informed our sampling efforts: because very few residents were captured in 2011, we focused on sites with higher proportions of residents in later years, biasing our sample against migrants. However, even after controlling for the effects of site, the proportion of residents still varied significantly across years (Cochran-Mantel-Haenszel test, $\mathrm{M}^{2}=14.6, \mathrm{df}=2, \mathrm{p}=0.0007$ ).

\section{Individual correlates of migratory strategy}

To determine whether individual characteristics affected migratory strategies, we used a dataset of 131 bluebirds ( 20 of which were captured multiple times) to conduct a logistic regression with migratory strategy as the response variable. The minimum adequate model included age, sex, and the interaction between age and sex as fixed effects; tarsus length was excluded from the final model. Age and the age-sex interaction were the only significant variables; sex was not significant as a main effect $(\mathrm{z}=-1.56, \mathrm{p}=0.12)$. Young (SY) birds were less likely to migrate than older (ASY) birds ( $\mathrm{z}=-2.54, \mathrm{p}=0.01$; Figure 3$)$, and SY females were less likely to migrate than SY males $(\mathrm{z}=1.96, \mathrm{p}=0.05$; Figure 3$)$.

\section{Breeding correlates of migratory strategy}

Western bluebirds paired assortatively by migratory strategy (chi-squared test; $\mathrm{X}^{2}=23.10, \mathrm{df}=1$, $\mathrm{p}<0.001)$. Of the 44 pairs in which we assigned migratory strategy to both the male and the female, 39 were mated assortatively ( 22 were both migrants and 17 were both residents), and only 5 were mated disassortatively ( 2 had a male migrant and female resident, and 3 had a male resident and a female migrant). In addition, $\delta D_{c}$ signatures were correlated between members of a pair (Spearman rank correlation; $\rho=0.74$, $\mathrm{p}<0.001$; Figure 4), suggesting that they wintered in the same place.

\section{Discussion}

\section{Individual and population patterns of migration}

Claw hydrogen isotope signatures allowed us to determine the migratory strategy of 158 of the 203 western bluebirds we captured (78\%). Of those 158, 86 (54.4\%) were migrants and 67 (42.4\%) were residents. We also determined that strategy was not fixed: 5 of the 23 birds captured in multiple years changed strategies between winters. While studies of some partially migratory systems have found strategy switching to be uncommon (e.g., Gillis et al. 2008, Townsend et al. 2018), our results are consistent with the larger number of studies that have found individual strategies are flexible (e.g., Able and Belthoff 1998, Ogonowski

'This article is protected by copyright. All rights reserved.' 
and Conway 2009, Palacín et al. 2011, Hegemann et al. 2015). The occurrence of strategy switching in western bluebirds suggests that migratory strategy is not controlled by a simple genetic dimorphism in this system.

Although our sample size was small, all five of the birds that switched strategy changed from migratory in the first winter to resident in the second winter. While this pattern has been observed in other species (Able and Belthoff 1998, Ogonowski and Conway 2009), it usually occurs in systems where young birds are more likely to migrate than older birds. In species where age and migratory strategy are not correlated, birds have been observed to switch both from migration to residency and the reverse (Palacín et al. 2011, Hegemann et al. 2015). In our study, younger birds were less likely to migrate than older birds (Figure 3), and we observed strategy switching in both young ( $\mathrm{SY}, \mathrm{n}=1$ ) and older (ASY, n=4) individuals, suggesting that switching may be independent of age. The single direction of switching could be explained if there is a fitness advantage to residency in bluebirds, as has been found in other partial migrants (e.g., Adriaensen and Dhondt 1990, Warkentin et al. 1990, Gillis et al. 2008, Grist et al. 2017).

All of the strategy switchers in our study were female. There is limited evidence regarding sex differences in migratory consistency in other systems, although Fudickar et al. (2013) reported that female European blackbirds were more likely than males to be obligate migrants, and Palacín et al. (2011) found that female great bustards switched migratory strategies in both directions, while males tended to move in one direction (from residency to migration) only. Our results raise the possibility that female migratory strategy is more flexible than male migratory strategy in bluebirds. However, because male bluebirds do not incubate and thus could not be box-trapped prior to our cut-off date, our sample size of recaptured males (in particular migrants) was quite small ( $\mathrm{n}=7$ males; 2 migrants and 5 residents). If migrant bluebirds are more likely to switch strategies than residents, we would have been unlikely to detect strategy switching in males even if it were occurring. Further studies are required to determine whether individual flexibility in migratory strategy differs between male and female bluebirds.

The proportion of bluebirds remaining resident during the winter varied significantly across the three years of the study. This variation was at least partly an artefact of annual differences in the distribution of sampling effort across sites; however, it remained significant after controlling for the effect of site, suggesting it may reflect real changes in migratory strategy. Christmas Bird Count data indicate that the 
number of winter resident bluebirds in the Okanagan has been increasing over the past thirty years (Willis 2013; see Supplementary material Appendix 1, Figure A1), but Willis (2013) found that the increase was best explained by increases in the breeding population, rather than a shift in migratory strategies. Nonetheless, increasing levels of residency have been observed in other partially migratory species (Berthold 1996, 2001, Pulido and Berthold 2010, Heath et al. 2012, Gilbert et al. 2016, Holte et al. 2016 - but see Nilsson et al. 2006, Meller et al. 2016), and are thought to be a response to recent changes in climate and land use.

Continued monitoring of the Okanagan and Rock Creek western bluebird populations is necessary to determine whether variation in the proportion of residents is a reflection of a shift in strategies in British Columbia.

The proportion of individuals remaining resident also varied across study sites: while both strategies were observed at all sites (with the exception of Thomas Ranch and Central Valley; Figure 1), in most cases, one strategy dominated. Furthermore, the proportion of residents at a site was highly correlated across years. The variation between and consistency within sites could be explained if sites differ in quality. For example, migration strategy could determine settlement patterns if sites vary in quality during the breeding season, such that resident birds may claim high quality sites before migrants return (e.g., Warkentin et al. 1990). Alternatively, territory quality during the nonbreeding season could shape migratory strategy, if birds with territories allowing access to high quality food are likely to stay (e.g., Aparicio 2000).

\section{Individual correlates of migratory strategy}

Our results did not support the dominance or body size hypotheses; however, they may provide some support for the arrival time hypothesis. Sex and body size were not related to migratory strategy, but age was: second year birds were significantly more likely to be resident than older birds (Figure 3). This was unexpected, as when migratory strategy differs between age classes, younger birds are usually more likely to migrate (e.g., Smith and Nilsson 1987, Able and Belthoff 1998, Ogonowski and Conway 2009). However, the pattern we detected is at least partially consistent with the arrival time hypothesis. Older (ASY) bluebirds usually return to the same territory, and often to the same box, to breed each year (Keyser et al. 2004, CAD pers. obs.), while SY males have a harder time establishing territories and are often supplanted by older males (Brawn 1984). Thus, SY birds may benefit more than ASYs from residency, as they are competing for the available high quality territories.

'This article is protected by copyright. All rights reserved.' 
However, the arrival time hypothesis cannot explain our finding that SY females were the sex-age class most likely to remain resident (Figure 3). If the importance of early arrival were driving the age patterns observed, we would expect SY males, not females, to be most likely to remain resident. One explanation for our results is that residency could be linked with increased overwinter survival in juvenile females. Our sample sizes provide circumstantial support for this hypothesis: the total number of birds captured in all other sex-age classes were relatively consistent (ASY males: $n=48$, SY males: $n=45$, ASY females: $n=43$ ), while the total number of SY females captured was notably smaller ( $n=17$; ratio of ASY:SY females=2.5). The relative paucity of SY females may suggest that winter survival is particularly low in this sex-age class. Alternatively, however, migratory SY females may simply be less likely to return to the Okanagan to breed than ASY females. Natal dispersal is female biased in western bluebirds (Dickinson et al. 2016), and if migrant females disperse farther than resident females, they may be more likely to disperse beyond the bounds of our study site to breed. Currently there are no data to suggest that migrants disperse farther than residents in partially migratory systems; however, both natal dispersal distance (Dingemanse et al. 2003) and migratory tendency (Nilsson et al. 2010, Chapman et al. 2011c) have been linked to individual characteristics such as boldness.

\section{Breeding correlates of migratory strategy}

We found strong evidence of assortative mating by migratory strategy in western bluebirds: in 39 of 44 pairs, the male and female shared the same migratory strategy. Assortative mating by migratory strategy has been observed in a number of other species (e.g., Eurasian blackcaps (Sylvia atricapilla), Bearhop et al. 2005; American kestrels (Falco sparverius), Anderson et al. 2016). However, in these species, assortative mating appears to be a result of differences in the timing of arrival and breeding initiation. In species where breeding phenology does not differ between migrants and residents, studies have found no evidence of assortative mating (e.g., skylarks, Hegemann et al. 2015). In Okanagan bluebirds, migratory strategy is not related to the timing of breeding (C. Dale, unpublished data), suggesting that assortative mating in our system is not an artefact of breeding phenology. It is possible that assortative mating in bluebirds could be a result of the variation among sites in the proportion of residents: if local populations are composed primarily of only migrants or only residents, assortative mating by migratory strategy would inevitably result. However, we

'This article is protected by copyright. All rights reserved.' 
also found that $\delta \mathrm{D}_{\mathrm{c}}$ signatures were significantly correlated between members of a pair (Figure 4), suggesting that members of a pair shared a winter location.

This correlation in $\delta \mathrm{D}_{\mathrm{c}}$ signatures could arise in two (non-mutually exclusive) ways. First, birds could pair during the winter and return to the breeding grounds paired, resulting in assortative mating by migratory strategy. Studies of western bluebirds in California suggest that pairing begins in winter flocks; aggressive interactions both within flocks (Kleiber et al. 2007) and towards intruders (Dickinson et al. 2009) are best explained by sexual competition, and males often pair with females from their winter flocks (Kraiijeveld and Dickinson 2001). Alternatively, the reverse might be true: a bluebird's migratory strategy might be affected by social influences, such as the migratory strategy of its mate. The pattern we observed was similar to that reported in Tasmanian silvereyes. As in bluebirds, patterns of migration in silvereyes do not match the predictions of the arrival time, dominance, or body size hypotheses (Chan and Kikkawa 1997). To explain variation in migratory strategy in this species, Chan (2005) proposed the "genetic-social" hypothesis, which suggests that social influences play a role in migratory decisions. Silvereyes mate for life, and members of a pair are often recaptured on the same date in the spring, suggesting they winter together (Chan and Kikkawa 1997, Chan 2005). Chan (2005) proposed that in silvereyes with intermediate migration thresholds (facultative migrants), the decision to migrate depends on social influences, and they are likely to migrate only if their mates or winter flock are migrating.

Although social or cultural influences have been suggested as drivers of migratory decisions in a few studies (e.g., Palacín et al. 2011, Barnowe-Meyer et al. 2013, Chambon et al. 2018), the importance of the social environment in partial migration remains relatively unexplored. However, our results suggest that social influences may help to explain individual variation in migratory behaviour in western bluebirds, where - like silvereyes - pairings may persist over multiple breeding seasons (Dickinson et al. 1996, C. Dale, unpublished data). Anecdotal evidence from our study also hints at the importance of social factors: in four of the five cases of strategy switching we observed, the male's migratory strategy was also known, and in three of these four cases, switching was associated with either disassortative mating, mate switching, or both.

\section{Conclusions}

Our study adds to a growing number of partial migration studies that have found the mechanisms shaping individual variation in migratory strategies are rarely as simple as the arrival time, dominance, and

'This article is protected by copyright. All rights reserved.' 
body size hypotheses. Future studies should aim to consider a wider variety of environmental variables, including the social environment, when attempting to disentangle the causes of individual variation in migratory behaviour. Understanding this variation is an important goal, particularly given recent observations of human-induced changes to the incidence, amount, direction and distance of migration in migratory birds worldwide. Without an understanding of the factors that drive migration decisions in partially migratory species, it will be virtually impossible to predict how these species - and the many ecosystems with which they interact - will respond to future changes in climate and land use.

Acknowledgements - We thank T. Belluz, M. Bhardwaj, A. Boag, J. Dale, S. Linn, L. McKinnon, L. Meads, J. Pomfret, C. Toth, and C. Willis for their help in the field, the staff of the Queen's Facility for Isotope Research, particularly K. Feige and A. Vuletich, for their assistance with isotope analyses, and A. Craig for her help producing maps. We also thank the many landowners and bluebird trail monitors that facilitated this research by allowing us access to their property and bluebird boxes: L. Chic, B. Galbraith, J. and A. Ginns, M. Gustavus, M. Hikichi, S. Linn, C. and L. McCall, D. McLarty, L. Meads, L. and H. Neilsen, L. Rockwell, J. and M. Wyse and the Burrowing Owl Estate Winery staff, M. and I. Mavety and the Blue Mountain Vineyard and Cellars staff, Blasted Church Vineyards, Fairview Mountain Golf Course, Hester Creek Estate Winery, Noble Ridge Vineyard and Winery, Road 13 Vineyards, See Ya Later Ranch, Tinhorn Creek Vineyards, the City of Penticton, and the Nature Trust of British Columbia. Christmas Bird Count data were provided by the National Audubon Society (www.audubon.org, www.christmasbirdcount.org) and through the generous efforts of Bird Studies Canada (www.bsc-eoc.org) and countless volunteers across the western hemisphere. Funding - Funding for this project was provided by J. Fotheringham, the Cooper Ornithological Society, the Wilson Ornithological Society, the North American Bluebird Association, the New York State Bluebird Society, the Southern Interior Bluebird Trail Association, Queen's University, the Canadian Foundation for Innovation, and the Natural Sciences and Engineering Research Council of Canada (NSERC; CAD, LMR, TKK).

Conflicts of interest - The authors declare that they have no conflicts of interest.

Permits - All work complied with Canadian laws and was performed in accordance with permits issued by the Queen's University Animal Care Committee (Ratcliffe-2010-046), Canadian Wildlife Services (banding permit 10829 and collection permit BC-11-0001), and BC Parks (use permit 104985).

'This article is protected by copyright. All rights reserved.' 


\section{References}

Able, K.P. and Belthoff, J.R. 1998. Rapid 'evolution' of migratory behaviour in the introduced house finch of eastern North America. - Proc. R. Soc. B 265: 2063-2071.

Adriaensen, F. and Dhondt, A.A. 1990. Population dynamics and partial migration of the European robin (Erithacus rubecula) in different habitats. - J. Anim. Ecol. 59: 1077-1090.

Anderson, A.M., Novak, S.J., Smith, J.F., Steenhof, K. and Heath, J.A. 2016. Nesting phenology, mate choice, and genetic divergence within a partially migratory population of American kestrels. -Auk 133: 99-109.

Aparicio, J. M. 2000. Differences in the diets of resident and non-resident kestrels in Spain. Ornis Fennica 77: $169-175$.

Barnowe-Meyer, K.K., White, P.J., Waits, L.P. and Byers, J.A. 2013. Social and genetic structure associated with migration in pronghorn. - Biol. Conserv. 168: 108-115.

Bearhop, S., Fiedler, W., Furness, R.W., Votier, S.C., Waldron, S., Newton, J., Bowen, G.J., Berthold, P. and Farnsworth, K. 2005. Assortative mating as a mechanism for rapid evolution of a migratory divide. Science 310: 502-504.

Bearhop, S., Furness, R.W., Hilton, G.M., Votier, S.C. and Waldron, S. 2003. A forensic approach to understanding diet and habitat use from stable isotope analysis of (avian) claw material. - Funct. Ecol. 17: 270-275.

Belthoff, J.R. and Gauthreaux, S.A. 1991. Partial migration and differential winter distribution of house finches in the eastern United Sates. - Condor 93: 374-382.

Berthold, P. 1988. Evolutionary aspects of migratory behavior in European warblers. - J. Evol. Biol. 1: 195209.

Berthold, P. 1996. Control of bird migration. - Chapman \& Hall.

Berthold, P. 2001. Bird migration: a general survey ( $2^{\text {nd }}$ edition). - Oxford University Press.

Berthold, P., and Querner, U. 1981. Genetic basis of migratory behavior in European warblers. - Science 212: 77-79.

Berthold, P., and Querner, U. 1982. Partial migration in birds: experimental proof of polymorphism as a controlling system. - Experientia 38: 805-806.

'This article is protected by copyright. All rights reserved.' 
Berthold, P., Helbig, A.J., Mohr, G. and Querner, U. 1992. Rapid microevolution of migratory behaviour in a wild bird species. - Nature 360: 668-670.

Berthold, P., Wiltschko, W., Miltenberger, H. and Querner, U. 1990. Genetic transmission of migratory behavior into a nonmigratory bird population. - Experientia 46: 107-108.

Biebach, H. 1983. Genetic determination of partial migration in the European robin (Erithacus rubecula).Auk 100: 601-606.

Bowen, G.J., Wassenaar, L.I. and Hobson, K.A. 2005. Global application of stable hydrogen and oxygen isotopes to wildlife forensics. - Oecologia 143: 337-348.

Brawn, J. 1984. Defense of nest boxes by western bluebirds during the post-breeding season. - Condor 86: 494-495.

Bugajski, A., Reudink, M.W., Doucette, J.L. Franks, S.E., Wissel, B. and Somers, C.M. 2013. The complexity of cormorants: stable isotopes reveal multiple prey sources and feeding site switching. Can. J. Fish. Aquat. Sci. 70: 271-279.

Campbell, R. W., Dawe, N. K., McTaggart-Cowan, I., Cooper, J. M., Kaiser, G. W., McNall, M. C. E. and Smith, G. E. J. 1997. Western bluebird. - In: The Birds of British Columbia. Volume 3. Passerines: flycatchers through vireos. University of British Columbia Press, pp. 358-365.

Cannings, R. 2009. Birds of interior BC and the Rockies. - Heritage House Publishing Company.

Catry, P., Dias, M.P., Phillips, R.A. and Granadeiro, J.P. 2013. Carry-over effects from breeding modulate the annual cycle of a long-distance migrant: an experimental demonstration. - Ecology 94: 1230-1235.

Chamberlain, C.P., Blum, J.D., Holmes, R.T., Feng, X., Sherry, T.W. and Graves G.R. 1997. The use of isotope tracers for identifying populations of migratory birds. - Oecologia 109: 132-141.

Chambon, R., Dugravot, S., Paillisson, J.-M., Lemesle, J.-C., Ysnel, F. and Gélinaud, G. 2018. Partial migration in inexperienced pied avocets Recurvirostra avosetta: distribution pattern and correlates. J. Avian Biol.: e01549.

Chan, K. 1994. Nocturnal activity of caged resident and migrant silvereyes (Zosteropidae: Aves). - Ethology 96: 313-321.

Chan, K. 2005. Partial migration in the silvereye (Aves Zosteropidae): pattern, synthesis, and theories. Ethol. Ecol. Evol. 17: 349-363.

'This article is protected by copyright. All rights reserved.' 
Chan, K. and Kikkawa, J. 1997. A silvereye dilemma: to migrate or not to migrate? - Emu 97: 91-93.

Chapman, B.B., Brönmark, C., Nilsson, J.-Å. and Hansson, L.-A. 2011a. Partial migration: an introduction. Oikos 120: 1761-1763.

Chapman, B.B., Brönmark, C., Nilsson, J.-Å. and Hansson, L.-A. 2011b. The ecology and evolution of partial migration. - Oikos 120: 1764-1775.

Chapman, B.B., Hulthén, K., Blomqvist, D.R., Hansson, L.-A., Nilsson, J.-Å., Brodersen, J., Nilsson, P.A., Skov, C. and Brönmark, C. 2011c. To boldly go: individual differences in boldness influence migratory tendency. - Ecol. Lett. 14: 871-876.

Dale, C.A., and Leonard, M.L. 2011. Reproductive consequences of migration decisions by Ipswich Sparrows (Passerculus sandwichensis princeps). - Can. J. Zool. 89: 100-108.

Dickinson, J.L., Akçay, Ç., Ferree, E.D. and Stern, C.A. 2016. Western bluebirds: lessons from a marginal cooperative breeder. - In: Koenig, W.D. and Dickinson, J.L. (eds), Cooperative breeding: studies of ecology, evolution, and behavior. Cambridge University Press, pp. 19-38.

Dickinson, J.L., Euaparadorn, M., Greenwald, K., Mitra, C. and Shizuka, D. 2009. Cooperation and competition: nepotistic tolerance and intrasexual aggression in western bluebird winter groups. Anim. Behav. 77: 867-872.

Dickinson, J.L., Koenig, W.D. and Pitelka, F.A. 1996. Fitness consequences of helping in the western bluebird. - Behav. Ecol. 7: 168-177.

Dingemanse, N.J., Both, C., van Noordwijk, A.J., Rutten, A.L. and Drent, P.J. 2003. Natal dispersal and personalities in great tits (Parus major). Proc. R. Soc. B 270: 741-747.

Duckworth, R.A. 2006. Aggressive behaviour affects selection on morphology by influencing settlement patterns in a passerine bird. - Proc. R. Soc. B 273: 1789-1795.

Estep, M.F. and Dabrowski, H. 1980. Tracing food webs with stable hydrogen isotopes. - Science 209: 15371538.

Franks, S.E., Norris, D.R., Kyser, T.K., Fernández, G., Schwarz, B., Carmona, R., Colwell, M.A., Sandoval, J.C., Dondua, A., Gates, H.R., Haase, B., Hodkinson, D.J., Jiménez, A., Lanctot, R.B., Ortego, B., Sandercock, B.K., Sanders, F., Takekawa, J.Y., Warnock, N., Ydenberg, R.C. and Lank, D.B. 2012.

'This article is protected by copyright. All rights reserved.' 
Range-wide patterns of migratory connectivity in the western sandpiper Calidris mauri. - J. Avian Biol. 43: 155-167.

Fraser, K.C., Kyser, T.K., Robertson, R.J. and Ratcliffe, L.M. 2008. Seasonal patterns in hydrogen isotopes of claws from breeding wood-warblers (Parulidae): utility for examining migratory origins. -Avian Conserv. Ecol. 3: 2.

Fudickar, A., Schmidt, A., Hau, M., Quetting, M. and Partecke, J. 2013. Female-biased obligate strategies in a partially migratory population. - J. Anim. Ecol. 82: 863-871.

Gauthreaux, S.A. 1982. The ecology and evolution of avian migration systems. - In: Farner, D.S., King, J.R. and Parkes, K.C. (eds), Avian Biology. Volume 6. Academic Press, pp. 93-168.

Gilbert, N.I., Correia, R.A., Silva, J.P., Pacheco, C., Catry, I., Atkinson, P.W., Gill, J.A. and Franco, A.M.A. 2016. Impacts of landfill use on the movement and behaviour of resident white storks (Ciconia ciconia) from a partially migratory population. - Mov. Ecol. 4: 7.

Gillis, E.A., Green, D.J., Middleton, H.A. and Morrissey, C.A. 2008. Life history correlates of alternative migratory strategies in American dippers. - Ecology 89: 1687-1695.

Gilroy, J.J., Gill, J.A., Butchart, S.H.M., Jones, V.R. and Franco, A.M.A. 2016. Migratory diversity predicts population declines in birds. - Ecol. Lett. 19: 308-317.

Grist, H., Daunt, F., Wanless, S., Burthe, S.J., Newell, M.A., Harris, M.P. and Reid, J.M. 2017. Reproductive performance of resident and migrant males, females, and pairs in a partially migratory bird. - J. Anim. Ecol. 86: 1010-1021.

Guinan, J.A., Gowaty, P.A. and Eltzroth, E.K. 2008. Western Bluebird (Sialia mexicana). - In Rodewald, P.G. (ed), The Birds of North America. Cornell Lab of Ornithology. Retrieved from the birds of North America: https://birdsna-org.proxy.queensu.ca/Species-Account/bna/species/wesblu. doi: 10.2173/bna.510.

Hahn, S., Dimitrov, D., Rehse, S., Yohannes, E. and Jenni, L. 2014. Avian claw morphometry and growth determine the temporal pattern of archived stable isotopes. - J. Avian Biol. 45: 202-207.

Heath, J.A., Steenhof, K. and Foster, M.A. 2012. Shorter migration distances associated with higher winter temperatures suggest a mechanism for advancing nesting phenology of American kestrels Falco sparverius. - J. Avian Biol. 43: 376-384.

'This article is protected by copyright. All rights reserved.' 
Hegemann, A., Marra, P.P. and Tieleman, B.I. 2015. Causes and consequences of partial migration in a passerine bird. - Am. Nat. 186: 531-546.

Helbig, A.J. 1991. Inheritance of migratory direction in a bird species: a cross-breeding experiment with SEand SW-migrating blackcaps (Sylvia atricapilla). - Behav. Ecol. Sociobiol. 28: 9-12.

Hobson, K.A. and Wassenaar, L.I. 1997. Linking breeding and wintering grounds of neotropical migrant songbirds using stable hydrogen isotopic analysis of feathers. - Oecologia 109: 142-148.

Hobson, K.A., Wassenaar, L.I. and Bayne, E. 2004. Using isotopic variance to detect long-distance dispersal and philopatry in birds: an example with ovenbirds and American redstarts. - Condor 106: 732-743.

Holte, D., Köppen, U. and Schmitz-Ornés, A. 2016. Partial migration in a central European raptor species: an analysis of ring re-encounter data of common kestrels Falco tinnunculus. - Acta Ornithol. 51: 39-54.

Jahn, A.E., Levey, D.J., Hostetler, J.A. and Mamani, A. M. 2010. Determinants of partial bird migration in the Amazon Basin. - J. Anim. Ecol. 79: 983-992.

Jahn, A.E., Bravo, S.P., Cueto, V.R., Levey, D.J. and Morales, M.V. 2012. Patterns of partial avian migration in northern and southern temperate latitudes of the New World. - Emu 112: 17-22.

Ketterson, E.D. and Nolan Jr, V. 1976. Geographic variation and its climatic correlates in the sex ratio of eastern-wintering dark-eyed juncos (Junco hyemalis hyemalis). - Ecology 57: 679-693.

Keyser, A.J., Keyser, M.T. and Promislow, D.E.L. 2004. Life-history variation and demography in western bluebirds (Sialia mexicana) in Oregon. - Auk 121: 118-133.

Kleiber, D., Kyle, K., Rockwell, S.M. and Dickinson, J.L. 2007. Sexual competition explains patterns of individual investment in territorial aggression in western bluebird winter groups. - Anim. Behav. 73: 763-770.

Langin, K.M., Reudink, M.W., Marra, P.P., Norris, D.R., Kyser, T.K. and Ratcliffe, L.M. 2007. Hydrogen isotopic variation in migratory bird tissues of known origin: implications for geographic assignment. - Oecologia 152: 449-457.

Lundberg, P. 1985. Dominance behaviour, body weight and fat variations, and partial migration in European blackbirds Turdus merula. - Behav. Ecol. Sociobiol. 17: 185-189.

Lundberg, P. 1988. The evolution of partial migration in birds. - Trends Ecol. Evol. 3: 172-175.

'This article is protected by copyright. All rights reserved.' 
Meller, K., Vähätalo, A.V., Hokkanen, T., Rintala, J., Piha, M. and Lehikoinen, A. 2016. Interannual variation and long-term trends in proportions of resident individuals in partially migratory birds. - J. Anim. Ecol. 85: 570-580.

Mettke-Hofmann, C. 2017. Avian movements in a modern world: cognitive challenges. - Anim. Cogn. 20: $77-86$.

National Audubon Society. 2010. The Christmas Bird Count Historical Results [Online]. Available http://www.christmasbirdcount.org [7 September 2017].

Nilsson, A.L.K., Lindström, Å., Jonzén, N., Nilsson, S.G. and Karlsson, L. 2006. The effect of climate change on partial migration - the blue tit paradox. - Glob. Chang. Biol. 12: 2014-2022.

Nilsson, A.L.K., Nilsson, J.-Å., Alerstam, T. and Bäckman, J. 2010. Migratory and resident blue tits Cyanistest caeruleus differ in their reaction to a novel object. - Naturwissenschaften 97: 981-985.

Ogonowski, M.S. and Conway, C.J. 2009. Migratory decisions in birds: extent of genetic versus environmental control. - Oecologia 161: 199-207.

Palacín, C., Alonso, J.C., Alonso, J.A., Magaña, M. and Martín, C.A. 2011. Cultural transmission and flexibility of partial migration patterns in a long-lived bird, the great bustard Otis tarda. - J. Avian Biol. 42: 301-308.

Pérez, C., Granadeiro, J.P., Dias, M.P., Alonso, H. and Catry, P. 2014. When males are more inclined to stay at home: insights into the partial migration of a pelagic seabird provided by geolocators and isotopes. - Behav. Ecol. 25: 313-319.

Pulido, F. 2011. Evolutionary genetics of partial migration - the threshold model of migration revis(it)ed. Oikos 120: 1776-1783.

Pulido, F. and Berthold, P. 2010. Current selection for lower migratory activity will drive the evolution of residency in a migratory bird population. - Proc. Natl Acad. Sci. USA 107: 7341-7346.

Pulido, F., Berthold, P. and van Noordwijk, A. 1996. Frequency of migrants and migratory activity are genetically correlated in a bird population: evolutionary implications. - Proc. Natl Acad. Sci. USA 93: $14642-14637$.

Pyle, P. 1997. Identification guide to North American birds. Part 1: Columbidae to Ploceidae. - Slate Creek Press.

'This article is protected by copyright. All rights reserved.' 
R Core Team. 2015. R: a language and environment for statistical computing. R Foundation for Statistical Computing. http://www.R-project.org/.

Rocque, D.A., Ben-David, M., Barry, R.P. and Winker, K. 2006. Assigning birds to wintering and breeding grounds using stable isotopes: lessons from two feather generations among three intercontinental migrants. - J. Ornithol. 147: 395-404.

Royle, J.A. and Rubenstein, D.R. 2004. The role of species abundance in determining breeding origins of migratory birds with stable isotopes. - Ecol. Appl. 14: 1780-1788.

Sandberg, R. and Moore, F.R. 1996. Migratory orientation of red-eyed vireos, Vireo olivaceus, in relation to energetic condition and ecological context. - Behav. Ecol. Sociobiol. 39: 1-10.

Sheppard, S.M.F., Nielsen, R.L. and Taylor, H.P. Jr. 1969. Oxygen and hydrogen isotope ratios of claw minerals from porphyry copper deposits. - Econ. Geol. 64: 755-777.

Shizuka, D. and Dickinson, J.L. 2005. Using molt limits to age western bluebirds. - J. Field Ornithol. 76: 193-196.

Smith, H.G. and Nilsson, J.-Å. 1987. Intraspecific variation in migratory pattern of a partial migrant, the blue tit (Parus caeruleus): an evaluation of different hypotheses. - Auk 104: 109-115.

Studds, C.E., Kyser, T.K. and Marra, P.P. 2008. Natal dispersal driven by environmental conditions interacting across the annual cycle of a migratory songbird. - Proc. Natl Acad. Sci. USA 105: 29292933.

Townsend, A.K., Frett, B., McGarvey, A. and Taff, C.C. 2018. Where do winter crows go? Characterizing partial migration of American Crows with satellite telemetry, stable isotopes, and molecular markers. - Auk 135: 964-974.

Warkentin, I.G., James, P.C. and Oliphant, L.W. 1990. Body morphometrics, age structure, and partial migration of urban merlins. - Auk 107: 25-34.

Wassenaar, L.I. and Hobson, K.A. 2001. A stable-isotope approach to delineate geographical catchment areas of avian migration monitoring stations in North America. - Environ. Sci. Technol. 35: 1845-1850.

Wilcove, D.S. and Wikelski, M. 2008. Going, going, gone: is animal migration disappearing? - PLoS Biology 6: e188. 
Willis, C.E. 2013. Are changes in climate and land-use associated with changes in migration strategies of western bluebirds (Sialia mexicana) in southern British Columbia? BSc Thesis. Queen's University, Kingston, Ontario, Canada.

Wunder, M.B., Kester, C.L., Knopf, F.L. and Rye, R.O. 2005. A test of geographic assignment using isotope tracers in feathers of known origin. - Oecologia 144: 607-617.

Wunder, M.B. and Norris, D.R. 2008. Improved estimates of certainty in stable-isotope-based methods for tracking migratory animals. - Ecol. Appl. 18: 549-559.

'This article is protected by copyright. All rights reserved.' 


\section{Figure Legends}

Figure 1. Map of study sites in the Okanagan Valley. Inset shows the location of the Okanagan Valley (outlined in red) in British Columbia, Canada, and overlaid pie charts show the proportion of migrants, residents, and birds that switched strategies captured at each site. The size of the pie charts reflects the total number of individuals assigned to a strategy at each site (all years pooled). Sample sizes range from 4 (Central Valley) to 35 (OK Falls Vineyards).
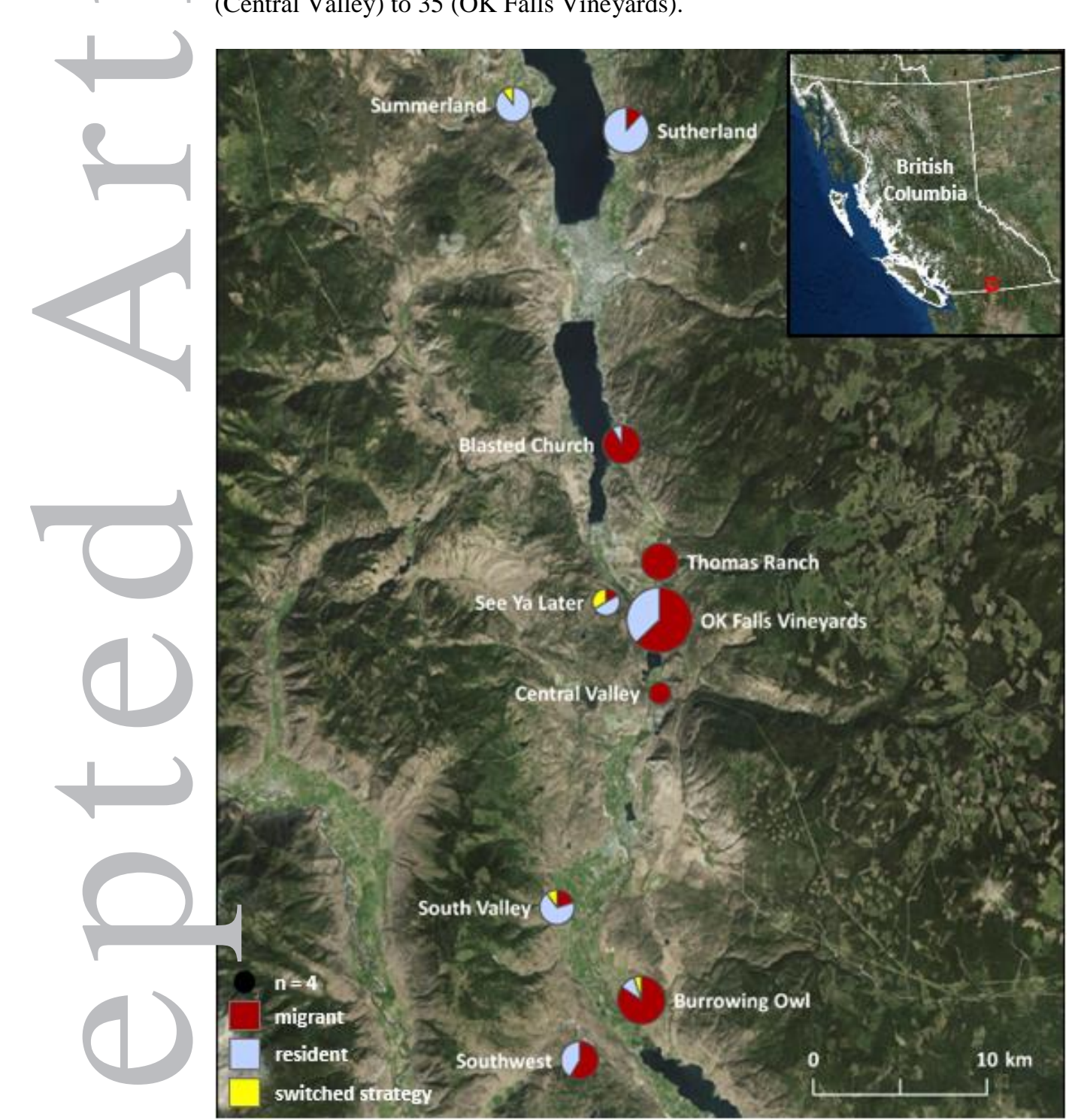

'This article is protected by copyright. All rights reserved.' 
Figure 2. (a) Claw $\delta \mathrm{D}$ signatures of known migrant $(\mathrm{n}=10)$ and known resident $(\mathrm{n}=12)$ western bluebirds; (b) Feather $\delta D$ signatures of assigned migrant $(n=20)$ and assigned and known resident $(n=10)$ western bluebirds. Midlines indicate median values, the whiskers extend to $1.5 \mathrm{x}$ the interquartile range, and open circles represent outliers. Significant differences are indicated by an asterisk.
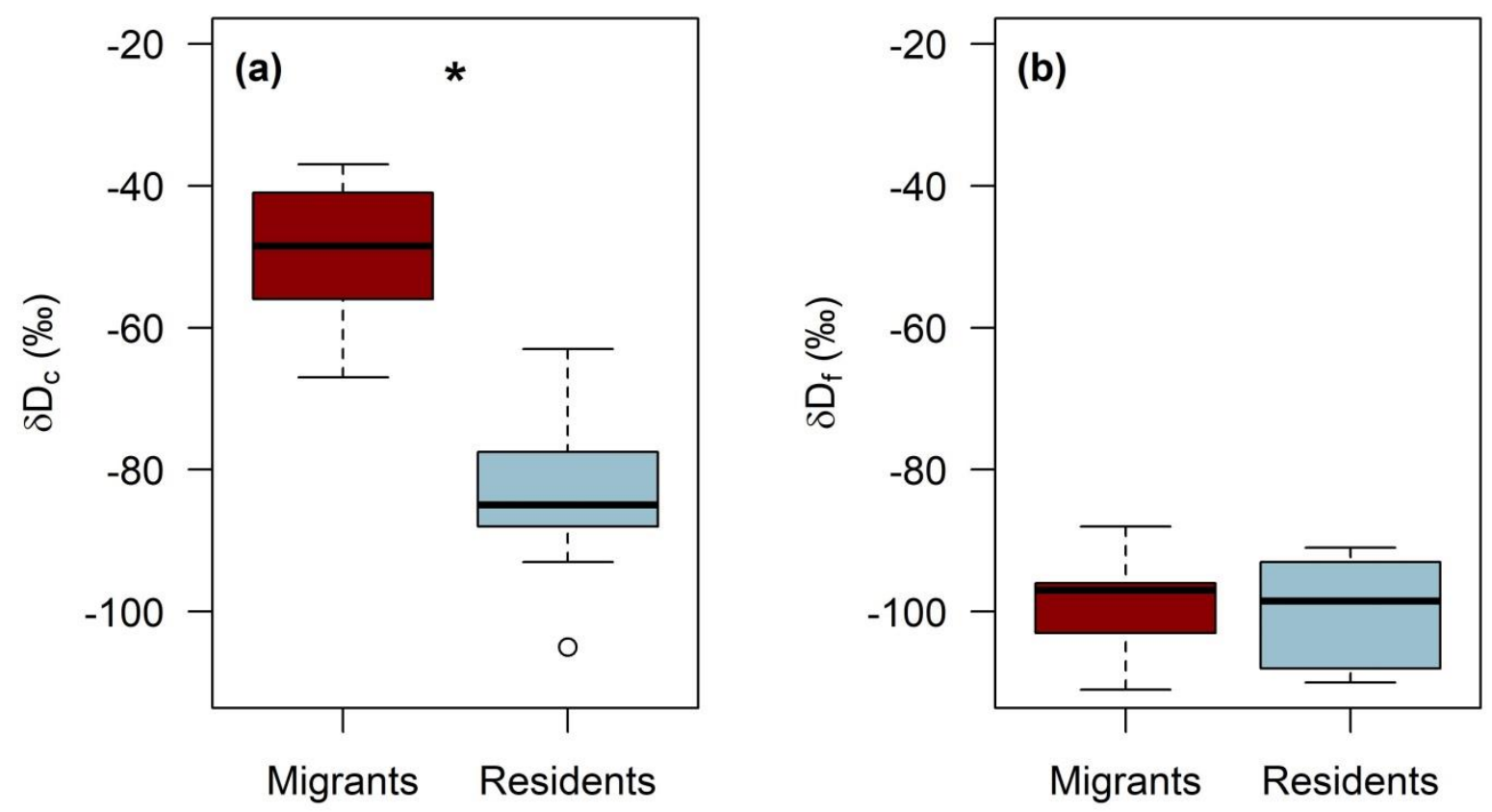

'This article is protected by copyright. All rights reserved.' 
Figure 3. Effect of sex and age on migratory strategy of western bluebirds in the Okanagan Valley. SY refers to second year birds, hatched the previous summer and in their first breeding season, while ASY refers to after second year birds. Bolded numbers in bars indicate sample sizes in each sex-age class. SY birds, particularly SY females, were significantly less likely to migrate than ASY birds.

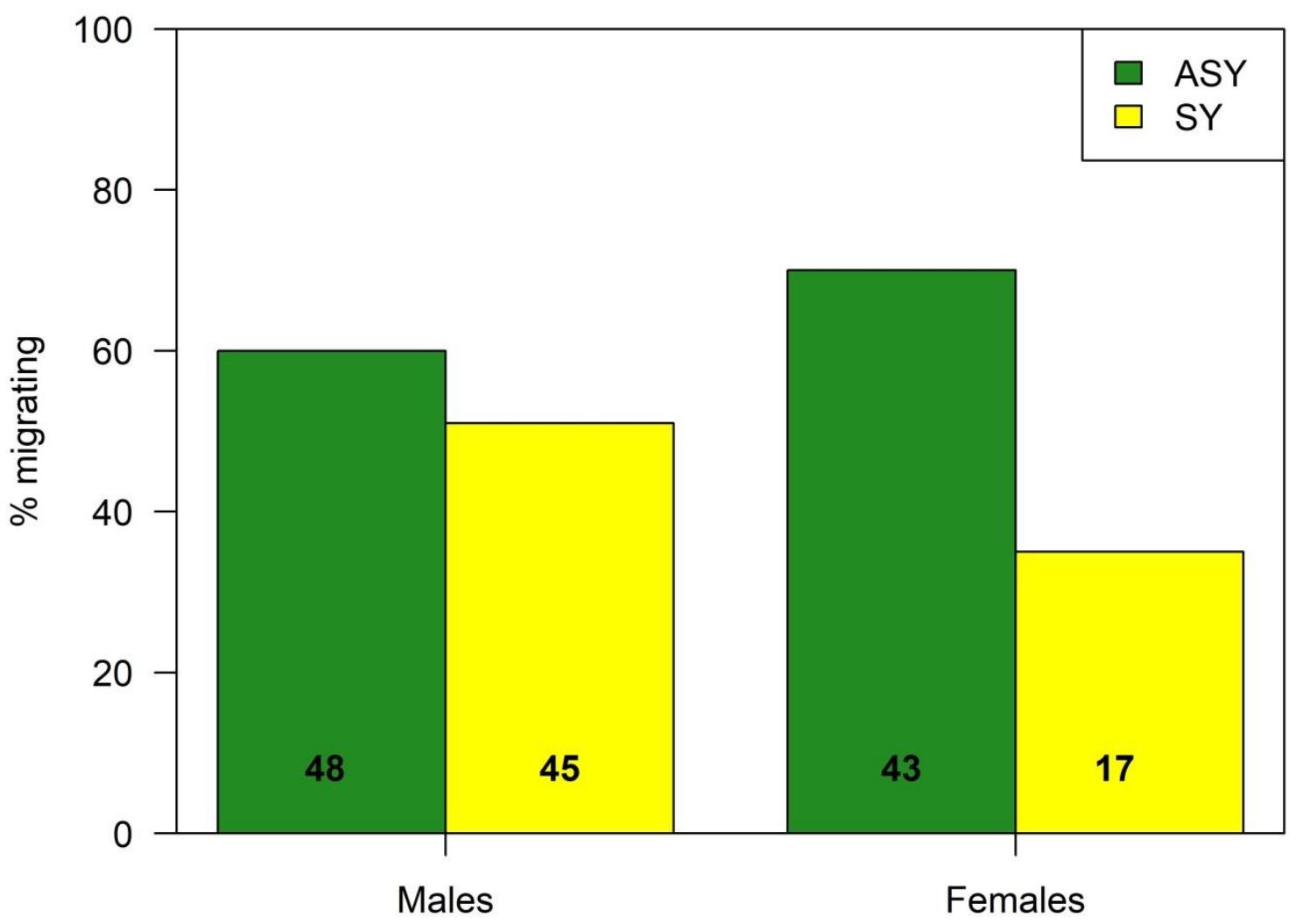

'This article is protected by copyright. All rights reserved.' 
Figure 4. Relationship between male and female claw $\delta \mathrm{D}$ signatures for 54 western bluebird pairs.

Assortatively mated pairs include migrant-migrant $(n=22)$ and resident-resident pairs $(n=17)$. Disassortatively mated pairs include those where the male was a resident and the female was a migrant $(n=3)$, and those where the male was a migrant and the female was a resident $(n=2)$. Unassigned pairs $(n=10)$ are those where, despite having $\delta \mathrm{D}$ signatures for both the male and female, we were unable to assign one or both birds to a migratory strategy with sufficient confidence.

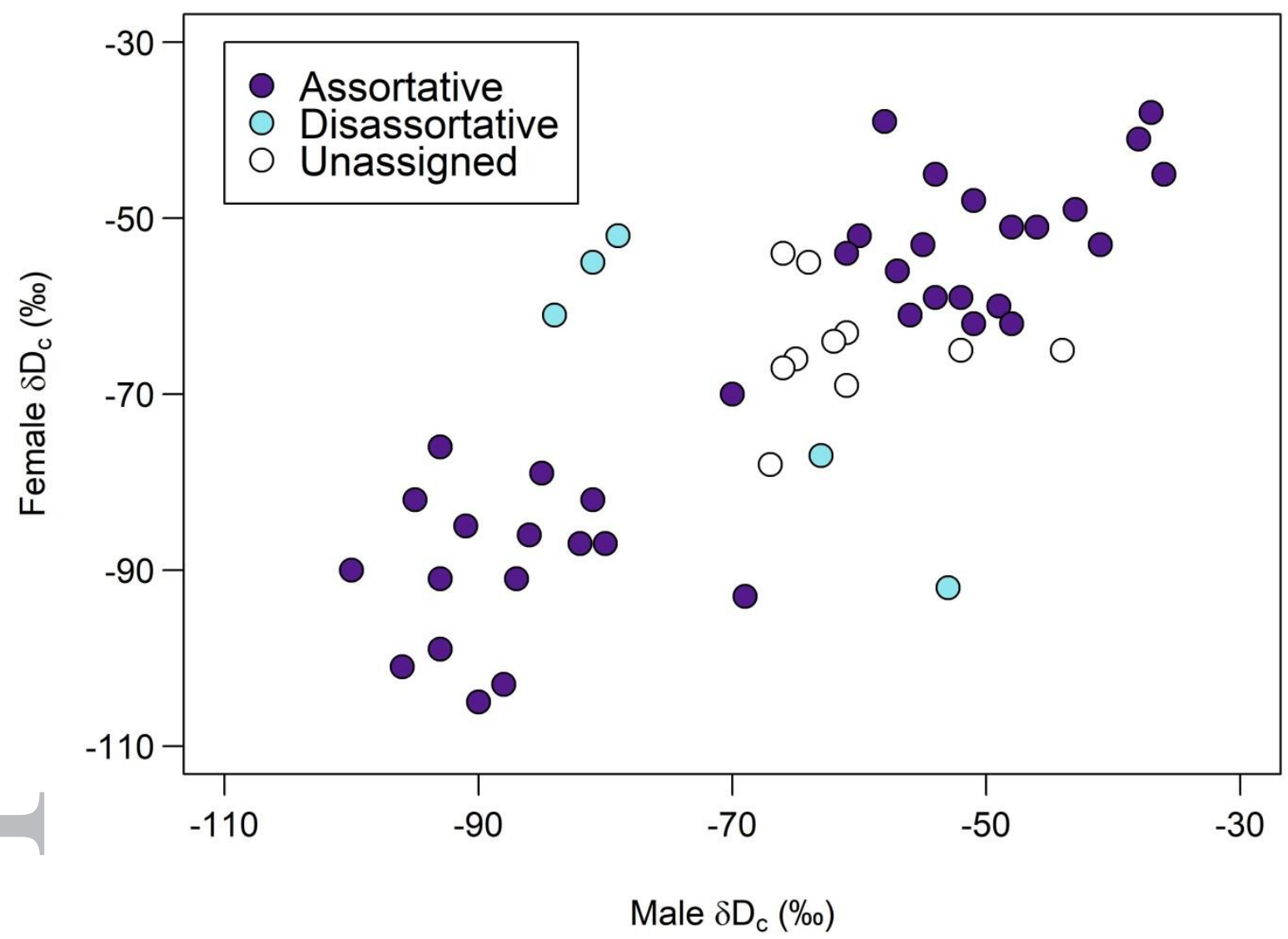

'This article is protected by copyright. All rights reserved.' 
Table Legends

Table 1. Mean and range of claw $\delta \mathrm{D}$ signatures by migratory strategy for bluebirds with known migratory strategies, and bluebirds assigned to migratory strategies using likelihood assignment testing.

\begin{tabular}{|lllll}
\hline & $\mathbf{n}$ & Mean (\%) & SD & Range (\%o) \\
\hline Known migrants & 10 & -49.5 & 10.07 & -67 to -37 \\
Assigned migrants & 92 & -52.6 & 7.00 & -63 to -36 \\
Known residents & 12 & -83.4 & 10.61 & -105 to -63 \\
\hline Assigned residents & 70 & -85.5 & 8.89 & -105 to -69 \\
\hline
\end{tabular}

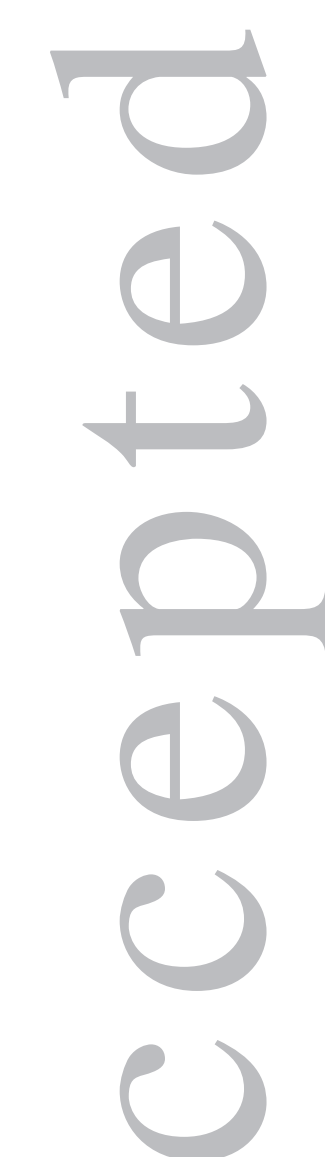

'This article is protected by copyright. All rights reserved.' 
Table 2. Number of known and assigned migrant and resident bluebirds by year of capture. Proportion of birds assigned to the resident strategy varied significantly over the course of the study.

\begin{tabular}{llll}
\hline Year & $\mathbf{2 0 1 1}$ & $\mathbf{2 0 1 2}$ & $\mathbf{2 0 1 3}$ \\
\hline Known Migrants & 6 & 4 & 0 \\
Assigned Migrants & 50 & 32 & 10 \\
Known Residents & 7 & 5 & 0 \\
Assigned Residents & 11 & 32 & 27 \\
Total & $\mathbf{7 4}$ & $\mathbf{7 3}$ & $\mathbf{3 7}$
\end{tabular}

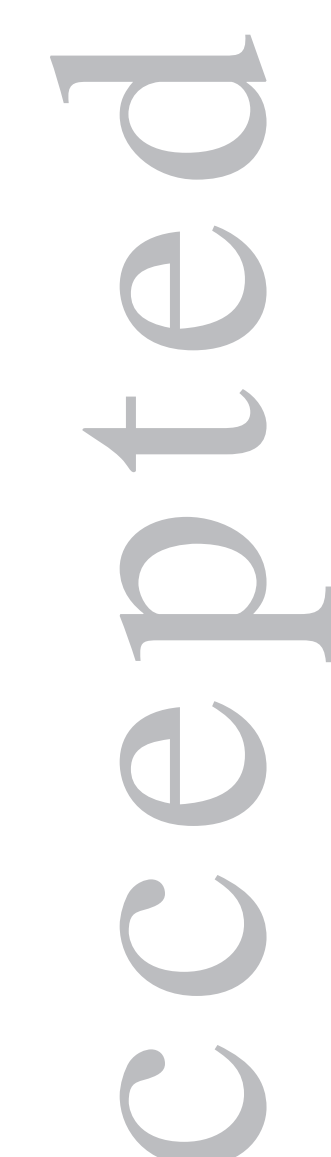

'This article is protected by copyright. All rights reserved.' 